\title{
Use of bioinsecticide and sugarcane molasses in the management of Cosmopolites sordidus (Germar) and Metamasius spp. (Horn)
}

\section{Uso de bioinseticida e melaço da cana-de-açúcar no manejo de Cosmopolites sordidus (Germar) e Metamasius spp (Horn)}

\author{
Nivânia Pereira da COSTA-MENEZES ${ }^{1}$; Valter da SILVA ${ }^{2}$; Maria José Araújo WANDERLEY ${ }^{3}$; Alberto \\ Nunes dos ANJOS ${ }^{4}$; Thiago de Sousa MELO ${ }^{5}$; Jacinto de Luna BATISTA ${ }^{5}$ \\ ${ }^{1}$ Autora para correspondência, Doutora, Universidade Federal da Paraíba, Campus III, Departamento de Agricultura, CEP \\ 58.220-000, Bananeiras, PB, nivania.menezes@academico.ufpb.br \\ ${ }_{2}^{2}$ Mestre em Ciências Agrárias (Agroecologia), Universidade Federal da Paraíba, Campus III, valtermataraca@gmail.com \\ ${ }^{3}$ Doutora, Universidade Federal da Paraíba, mjaw@academico.ufpb.br \\ ${ }^{4}$ Licenciando em Ciências Agrárias, Universidade Federal da Paraíba, Campus III, bertoanjos@gmail.com \\ ${ }^{5}$ Doutor, Universidade Federal da Paraíba, thiagosoumelo@hotmail.com; jacinto@cca.ufpb.br
}

Recebido em: 22-03-2021; Aceito em: 06-09-2021

\begin{abstract}
Banana (Musa spp.) is one of the most consumed fruits in the world, being of great economic importance to Brazil. However, insect pest attack has limited its production. This study aimed to monitor the populations of Cosmopolites sordidus and Metamasius spp. in areas of cultivation of bananas cv. Pacovan using a food attractant and a bioinsecticide in order to control their populations. The research was carried out in three rural properties, where roof tile-type baits made of pseudostems of banana trees, containing the treatments Boveril $(\mathrm{B}$ (bioinsecticide - Beauveria bassiana); sugarcane molasses; and the control treatment were set up. The baits, placed beside the clumps, were replaced every two weeks, and the adult insects were removed and counted weekly. Insect infestation was analyzed as a function of the treatments used in the baits, as well as of the influence of weather conditions on the banana weevil borer populations in the three properties. The randomized blocks experimental design was used, in a $3 \times 5$ factorial design (treatments and months of evaluation). The treatment-free baits were as efficient in collecting banana weevil borers as those containing the bioinsecticide and sugarcane molasses. The successive captures of $C$. sordidus with the use of the roof tile-type baits reduced the number of insects without the need for chemical control; the behavior of Metamasius spp. may have been influenced by local weather conditions; in two properties, two- to three-fold more individuals of Metamasius spp were captured in relation to $C$. sordidus, indicating high infestation of Metamasius spp. in the cultivar Pacovan.
\end{abstract}

Additional keywords: Banana weevil borers; Beauveria bassiana; food attractant; Musa spp.

\begin{abstract}
Resumo
A banana (Musa spp.) é uma das frutas mais consumidas no mundo e de grande importância econômica para 0 Brasil. No entanto, $\mathrm{O}$ ataque de insetos-pragas tem limitado a sua produção. $O$ objetivo desse trabalho foi monitorar as populações de Cosmopolites sordidus e Metamasius spp em áreas de cultivo de bananas, cv. Pacovan, usando atrativo alimentar e bioinseticida, com vistas ao seu controle. A pesquisa foi desenvolvida em três propriedades rurais onde foram instaladas armadilhas "tipo telha", confeccionadas com pseudocaule de bananeiras, contendo os tratamentos: Boveril ${ }^{\circledR}$ (bioinseticida - Beauveria bassiana); melaço de cana-de-açúcar e a testemunha. As armadilhas, posicionadas ao lado das touceiras, foram substituídas quinzenalmente, e semanalmente era feita a remoção e contagem dos insetos adultos. Foi analisada a infestação de insetos em função dos tratamentos utilizados nas armadilhas, bem como a influência das condições climáticas sobre a população das coleobrocas nas três propriedades. Utilizou-se o delineamento em blocos ao acaso, adotando o esquema fatorial $3 \times 5$ (tratamentos e meses de avaliação). As iscas isentas de tratamento foram tão eficientes na coleta das coleobrocas quanto aquelas contendo o bioinseticida e o melaço da cana-de-açúcar. As capturas sucessivas de $C$. sordidus com a utilização da isca "tipo telha" promoveu redução do número de insetos, sem a necessidade de controle químico; o comportamento de Metamasius spp. pode ter sido influenciado pelas condições climáticas locais; em duas propriedades, foram capturados de duas a três vezes o número de indivíduos de Metamasius spp. em relação a C. sordidus, indicando a elevada infestação de Metamasius spp., na cultivar Pacovan.
\end{abstract}

Palavras-chave adicionais: atrativo alimentar; Beauveria bassiana; brocas da bananeira; Musa sp. 


\section{Introduction}

The banana tree (Musa spp.), belonging to the family Musaceae, originated in Southeast Asia, is the most consumed fruit in the world, with Brazil being the second largest producer in the world, second only to India (Treichel et al., 2016). The Northeast region stands out as the main banana producing region in Brazil, producing 2,332,671 tons (t) in the 2019 agricultural year, followed by the Southeast region $(2,320,541 \mathrm{t})$ (IBGE, 2019). In the state of Paraíba, banana production in 2019 was 133,514 ton, with emphasis on the municipalities of Borborema, Bananeiras, and Alagoa Nova, located in the Brejo Paraibano microregion, whose share of bananas in the agricultural activity was $33.2 \%$ (Sousa \& Pereira, 2016).

Several insect pests affect the banana tree, reducing its production, especially the banana weevil borer Cosmopolites sordidus (Coleoptera: Curculionidae). When this insect attacks, galleries are formed in the rhizomes and in the lower part of pseudostems (Angelini \& Queiroz, 2016), weakening plants and making them more susceptible to tumbling, causing low yields (Bortoluzzi et al., 2013).

The cane weevil, Metamasius spp. (Coleoptera: Curculionidae), has also been a concern for banana growers, as some research have attributed possible injuries to the plant tissue to the cane weevil, especially when the infestation of this weevil borer is high. Larvae of Metamasius hemipterus open galleries in banana trees at a height between 20 and $100 \mathrm{~cm}$ from ground level, causing severe damage and predisposing the banana trees to have their pseudostem broken (Fancelli, 2012). Although Metamasius spp. is considered a pest of secondary importance, integrated management measures must be adopted to avoid large population outbreaks. Otherwise, their larvae will feed on the living tissues of the banana trees, causing superficial and deep galleries in the pseudostem (Kochemborger et al., 2016).

The control of the banana weevil borer should starts during banana planting through the acquisition of healthy seedlings, acquired from reputable nurseries or tissue culture laboratories. In the case of conventional seedlings, inspection must be carried out using attractive baits, such as tile- or cheese-type baits, for the capture and elimination of insects (Fancelli et al., 2015). Rojas et al. (2019) compared traps with attractants for monitoring $C$. sordidus and Metamasius spp. in banana trees and concluded that the pseudostem trap presented a better monthly mean capture of C. sordidus (3.11 individuals) and Metamasius spp. (7.81 individuals).

Additionally, some studies were carried out using traps containing entomopathogenic fungi. Dolinski \& Lacy (2007) carried out a review on the use of entomopathogens in the control of tropical fruit insects and showed that the control of the banana weevil borer can be performed successfully by using these control agents. López et al. (2012), who studied the transmission of the entomopathogenic fungus Beauveria bassiana in the control of $C$. sordidus, released healthy insects and later insects inoculated with the fungus. When recapturing the insects, they observed an infection rate of $3.7 \%$, characterizing transmission between inoculated and healthy insects due to the increase in the pre-existing natural prevalence, which was only $0.3 \%$ of sick insects.

Pauli et al. (2011) evaluated the horizontal spread of $B$. bassiana inoculated in roof tile-type baits in a banana plantation infested with $C$. sordidus and in another banana plantation with $C$. sordidus and $M$. hemipterus. They concluded that the transmission of the pathogen was more efficient in the area with the presence of the two weevil borers and $M$. hemipterus contributed to the spread of $B$. bassiana in the population of C. sordidus. Moreira et al. (2017) concluded that the biological control of $C$. sordidus with the fungus $B$. bassiana was more effective than with Metarhizium Anisopliae, especially at the concentration of $20 \mathrm{~g} \mathrm{~L}-1$. However, the producer needs to be aware that its application should begin before the pest is established in the crop.

This study aimed to monitor the populations of C. sordidus and Metamasius spp. in areas of banana cv. Pacovan cultivation using a food attractant and a bioinsecticide.

\section{Material and methods}

The study area is located in three rural properties in the Brejo Paraibano microregion, in the municipality of Bananeiras, where bananas (Musa spp.) are traditionally produced. According to the Brazilian Soil Classification, the experimental area presents a eutrophic red-yellow podzolic soil with a small part of Latosol. The climate, according to the Köppen climatic classification, is As-rainy tropical, with dry summers.

Monitoring was carried out in a monoculture system of banana trees cultivar Pacovan with approximately five years of age, planted with a spacing of $3 \times 3 \mathrm{~m}$.

During the research period, temperature ranged from 20.2 to $23.4{ }^{\circ} \mathrm{C}$; relative air humidity from 92.2 to $93.8 \%$; and an average rainfall of approximately $1,081.8 \mathrm{~mm}$ was recorded in the experimental area, as shown in Figure 1 (AESA, 2020).

In each property, four plots with an area of 200 $\mathrm{m}^{2}$ were demarcated. Then, the roof tile-type baits were prepared, made from the pseudostem of banana trees that had already been produced. The baits, measuring $40 \mathrm{~cm}$ in length, were cut longitudinally, receiving on the cut face one of the three following treatments: Boveri $\left(\AA\right.$ at a concentration of $1 \times 10^{9}$ viable conidia $\mathrm{g}^{-1}$ (as recommended by the manufacturer); 
sugarcane molasses diluted in water at $10 \%$; and the control (treatment-free).

In each plot, two baits were distributed per treatment, that is, six baits per plot. The baits, after receiving the treatments, were distributed beside the clumps of banana trees, with the cut part facing the ground. The baits were evaluated weekly in order to remove and count the adults, being replaced every fortnight. The insects collected in the baits were transported to the Entomology Laboratory, Center for Human, Social and Agrarian Sciences (CCHSA),
Federal University of Paraíba (UFPB), where screening was carried out to identify the genus and quantify of the specimens. The evaluation of the infestation of $C$. sordidus was carried out according to the methodology by Gallo et al. (2002), considering the control level of 5 adults/bait/month. The identification of the weevil borers ( $C$. sordidus and Metamasius spp.) was performed visually, observing the external morphological characteristics of the insects (Gallo et al., 2002).

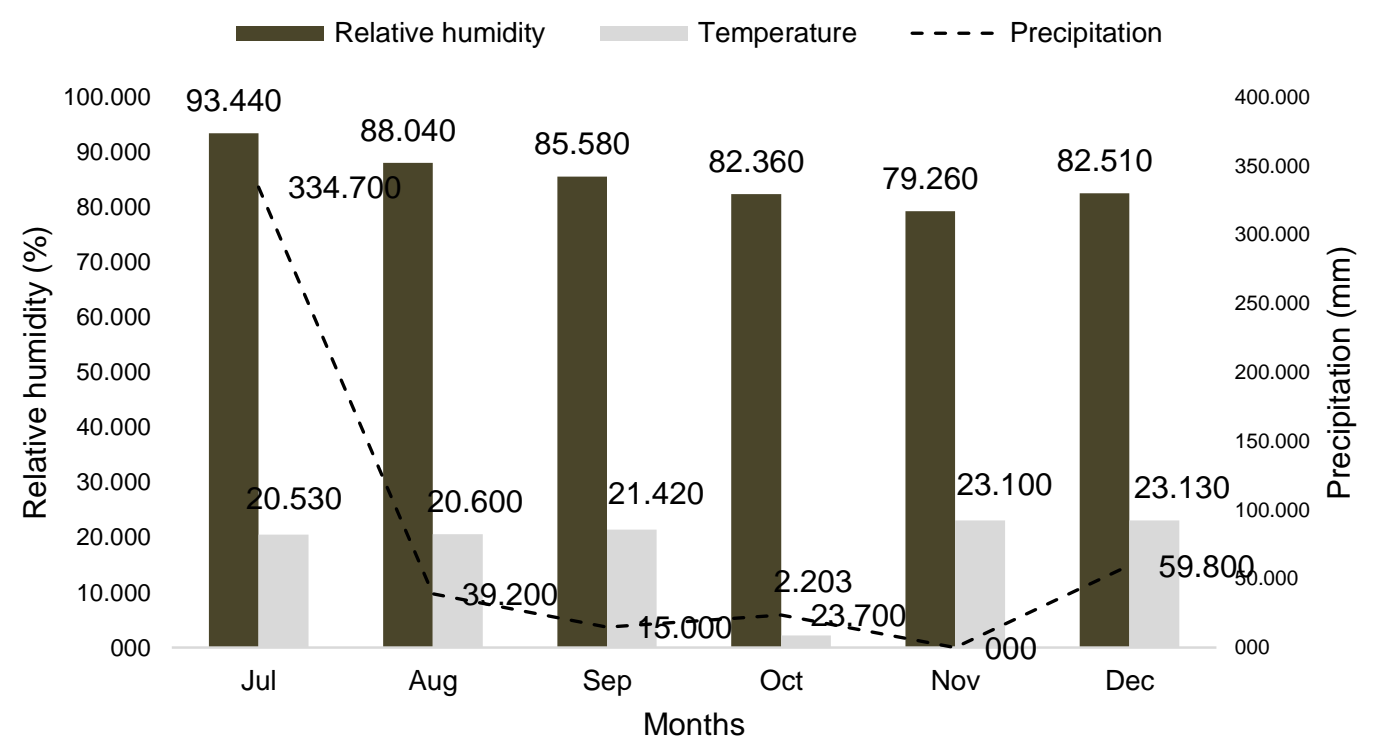

Figure 1 - Relative humidity, temperature, and precipitation recorded during the experimental period. Bananeiras, PB.

Insect infestation and the influence of climatic conditions on the population of banana weevil borers in the three properties were analyzed through the baits in the treatments. Rainfall, relative humidity, and air temperature data was collected monthly at the local agrometeorological station.

The following statistical model was used for analysis of the studied variables: $Y_{i j}=\mu+A_{i}+M_{j}+b_{1}\left(h_{j}\right.$ $-h)+b_{2}\left(h_{i}-h\right)^{2}+\alpha(A M)_{i j}+e_{i j}$, Where: $Y_{i j}=$ observation referring to the $i$-th level of the attractant with the $j$-th level of the months of the year in the $m$-th repetition; $\mu=$ overall mean of the experiment; $A_{i}=$ effect of attractiveness $i$, with $i=1,2$, and 3 ; where $1=$ Boveri $\AA$ at a concentration of $1 \times 10^{9}$ viable conidia $\mathrm{g}^{-1}, 2=$ sugarcane molasses diluted to $10 \%$, and $3=$ control; $M_{j}$ $=$ effect of months; $M_{\mathrm{i}}=$ effect of the months of the year; $b_{1}=$ linear coefficient of variable regression $y$ as a function of months; $b_{2}=$ quadratic coefficient of variable regression $y$ as a function of months; $h_{i}=$ levels of the months of year $j$, where $j=8 ; 9 ; 10 ; 11$; and 12 months of the year; $h=$ mean of the months of the year; $\mathrm{e}_{i j}=$ random error associated with each observation Yij.

The randomized blocks experimental design was used, in a $3 \times 5$ factorial design (treatments and months of evaluation) for each property. The data obtained were subjected to analysis of variance at a $5 \%$ probability level. In case of differences, the Duncan's test was applied to analyze the differences between means, with data being transformed into a root $(x+0.5)$. To describe the effect of the levels of the months of the year, regression analysis was performed, obtaining the curve that best described the behavior of the data, using the statistical software $R$ version 3.4.1 (R CORE TEAM, 2017).

\section{Results and discussion}

The number of adult insects of C.sordidus (banana weevil borer) and Metamasius spp. (cane weevil) and C. sordidus + Metamasius spp were not significantly affected $(P>0.05)$ (Table 1$)$ by the interaction between treatments and months of the year in the properties $\mathrm{A}, \mathrm{B}$, and $\mathrm{C}$. There was a difference $(p<0.01)$ in the capture of insects in the different properties as a function of the months of the year.

Quadratic effect $(p<0.01)$ was observed in the mean values of adult insects of $C$. sordidus, Metamasius spp. and C. sordidus + Metamasius spp. as a function of the months of the year in the three properties (Figure 2). In property A, C. sordidus 
presented an initial infestation within the expected for the level of control, which is five adults/bait/month, decreasing as the number of collections increased (Figure 2a), while in properties $\mathrm{B}$ and $\mathrm{C}$ (Figure $2 \mathrm{~b}$ and 2c), the number of $C$. sordidus was above the level of control and continued to decrease as the number of collections increased. The highest capture rates occurred in September for property A and in August for properties B and C.

Table 1 - Summary of the analysis of variance for the number of insects captured according to the treatments evaluated and the months of capture in each rural property.

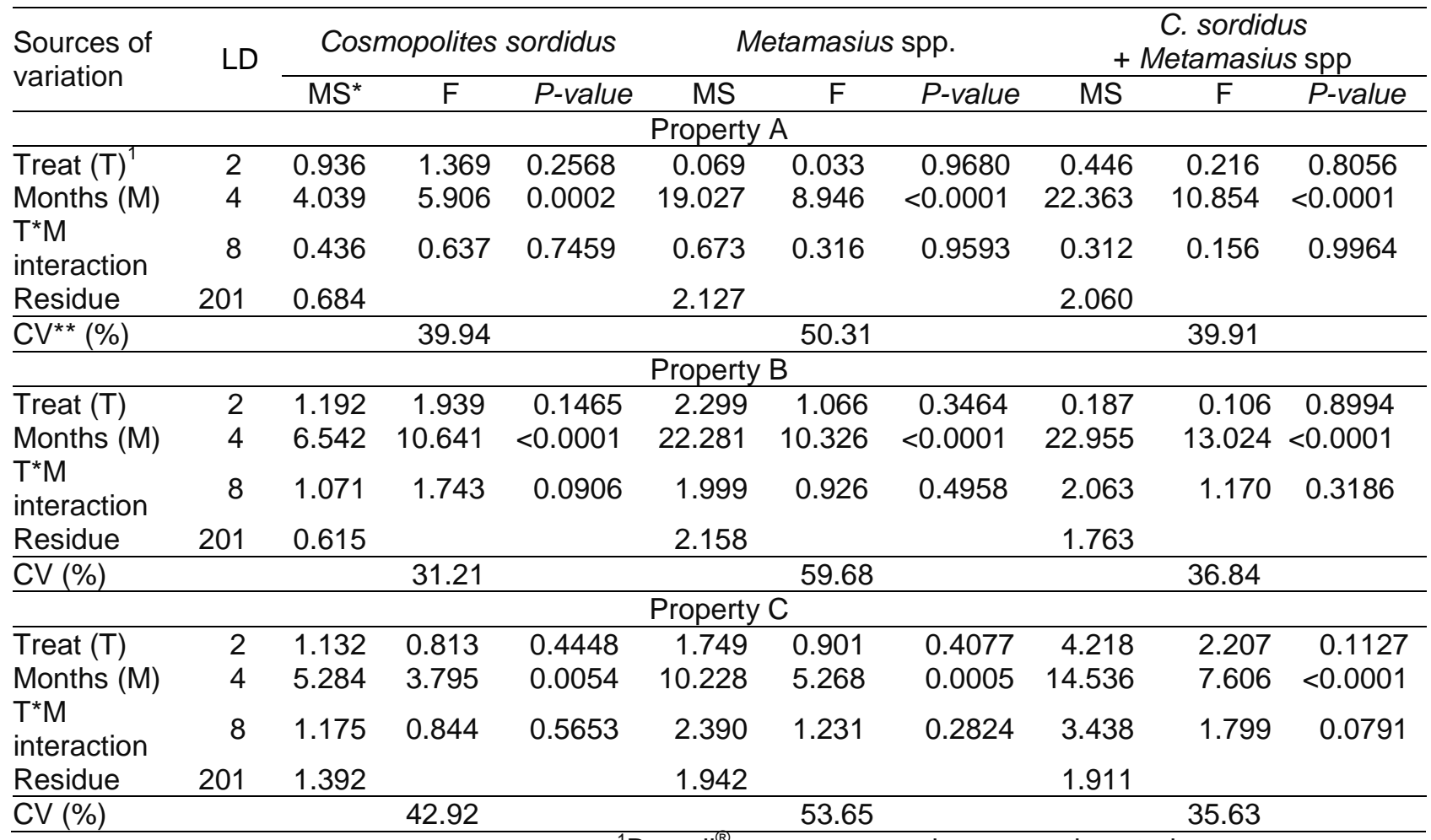

${ }^{*} \mathrm{MS}=$ mean squares; ${ }^{* *} \mathrm{CV}$ : coefficient of variation. ${ }^{1}$ Boveril ${ }^{\circledR}$, sugarcane molasses, and control.

At the beginning of the experiment (August) an average of 8.3 individuals of $C$. sordidus were collected on property $B$, decreasing in the subsequent months until the end of the experiment (December) (Figure 2b). On property C, 10.4 individuals of this species were collected in August, and at the end of the experiment (December), an average of 5.4 insects were collected per bait, showing that the initial infestation of the insect in this property was twice as high as indicated for the beginning of control. C. sordidus causes several yield losses, since the pest establishes itself in the plant rhizome, forming galleries and reducing the capacity to absorb water and nutrients, making the plants more susceptible to pathogens, even causing their tumbling, especially at bunch formation, making it necessary to adopt measures to reduce the pest population (Fancelli et al., 2015).

According to Moreira et al. (2017) successive collections of $C$. sordidus are important for the number of insects that are removed from the banana cultivation area. For these authors, the use of baits made from the pseudostem is also an important practice in the management of $C$. sordidus and can be recommended for small properties. Corroborating with these authors, in the present study, the use of baits promoted, in general, a gradual reduction in the capture of $C$. sordidus as the number of collections increased.

For Metamasius spp on property A, the average number of insects captured was smaller at the beginning of collections (August) and increased until October, followed by a decrease until the end of collections (December) (Figure 2a). The number of insects of this species collected in the baits in October (month that presented the largest number of captured insects) was three-fold higher than the number of $C$. sordidus captured. This behavior for Metamasius spp can be observed in properties B and C, where the highest collection rate was obtained in October for both properties (Figure $2 \mathrm{~b}$ and $2 \mathrm{c}$ ), and the number of Metamasius spp collected was almost two-fold higher than the number of $C$. sordidus insects collected in property B. According to Fancelli (2012), larvae of $M$. hemipterus bore the banana plants cv. Terra at a height between 0.2 and $1.0 \mathrm{~m}$ above ground level, contributing to its tumbling. 
- Cosmopolites sordidus $\bullet$ Metamasius spp $\Delta$ C. sordidus + Metamasius spp
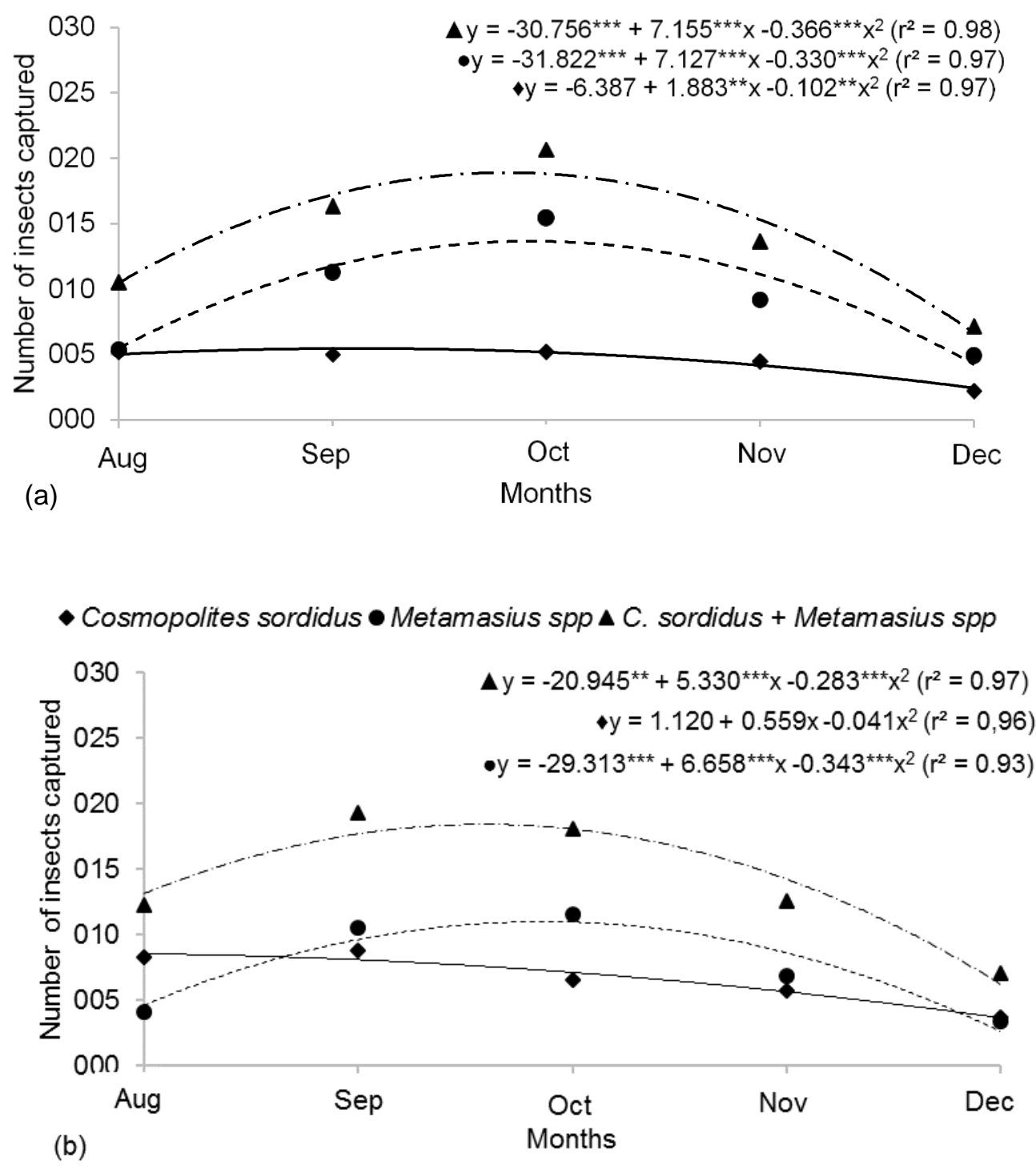

- Cosmopolites sordidus $\bullet$ Metamasius spp $\triangle$ C. sordidus + Metamasius spp

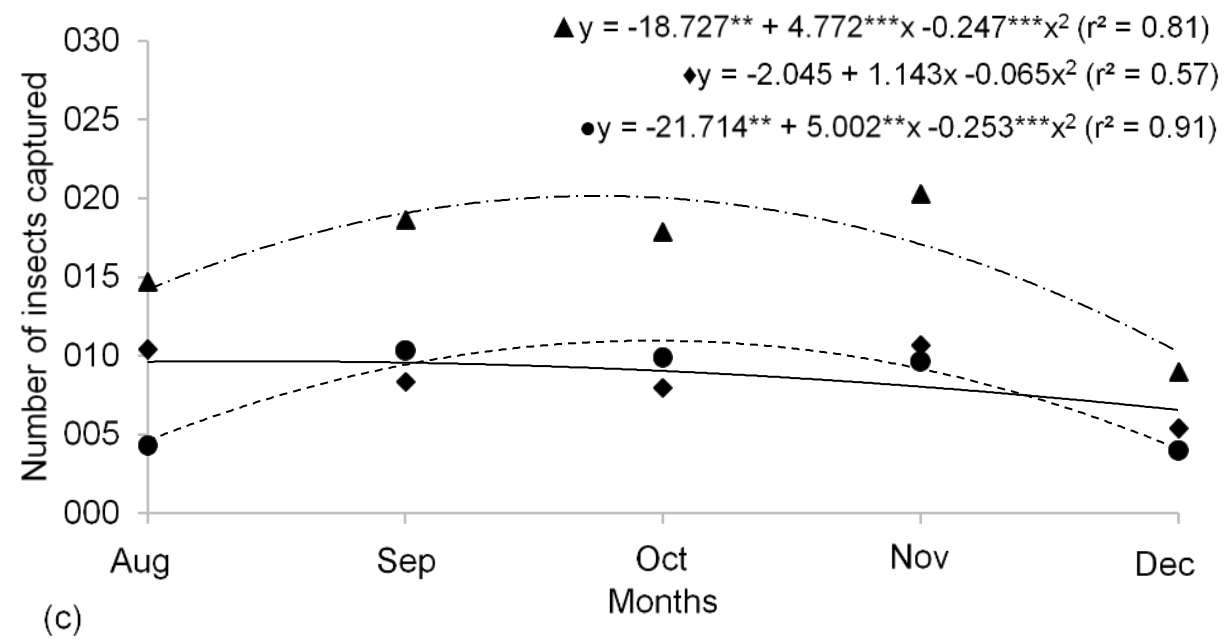

Figure 2 - Mean values of Cosmopolites sordidus and Metamasius spp. and C. sordidus + Metamasius spp. captured per month in three rural properties (A, B, and C). Bananeiras, PB. 
Although showing high infestation, we cannot affirm which was the level of control for Metamasius spp, as this information is not in the literature, requiring a more detailed study on the damage that this insect causes in the banana crop. Fancelli (2012) warned of the need to monitor the insect to support decisionmaking with a view to the need for control, in order to minimize damage to banana trees cv. Terra. The cane weevil (Metamasius spp.) has been attributed as a possible cause of injuries in the tissue of the banana tree, especially when this weevil borer presents high infestation (Kochemborger et al., 2016).

Considering the reports on Metamasius spp, it is important to pay special attention to its infestation levels in banana cv. Pacovan in the Brejo region, since the infestation of this insect in the present study exceeded by two to three-fold the number of $C$ sordidus in properties $A$ and $B$, values that are beyond what is indicated to start the control, which is 5.0 insects/bait/month for C. sordidus (Gallo et al., 2002).

Figure $2(2 \mathrm{a}, 2 \mathrm{~b}$ and $2 \mathrm{c})$ shows the monthly average of the sum of the number of insects of $C$ sordidus + Metamasius spp. captured from August to December. The capture peak in the three properties occurred in October, with a value close to 20 captured insects/month, showing the high infestation of these insects.

In field observations during this study, the occurrence of adults of Metamasius spp. was observed throughout the period evaluated, both in the baits as in the pseudostems of live plants and harvested plants. However, only Metamasius spp. found in the baits were counted. According to Dolinski \& Lacey (2007), $M$. hemipterus has great mobility using flight as a means of locomotion and dispersion, characterizing it as an efficient agent for the dissemination of entomopathogens, which can act in the biological control of C. sordidus. Pauli et al. (2011) concluded that $M$. hemipterus can promote the spread of conidia of $B$. bassiana, when applied by inoculation through attractive baits, which in the long term can increase the efficiency of this control strategy aimed at reducing the population of $C$. sordidus.

It is important to note that in all three properties, the infestation of Metamasius spp. in August, the beginning of the experiment, it was lower when compared to September, October, and November (Figure 2). It is noteworthy that in August, the relative humidity $(\mathrm{RH})$ was high $(88 \%)$ and rainfall was $39 \mathrm{~mm}$, while in the three subsequent months (September, October, and November) there was a decrease in $\mathrm{RH}(79.3 \%)$ and rainfall, 15; 23.7; and $0.0 \mathrm{~mm}$, respectively (Figure 1 ), showing that at the time when there was less precipitation and decreased $\mathrm{RH}$, there was a reduction in the capture of Metamasius spp. There was little variation in temperature during the experiment.

Environmental factors such as humidity and temperature can interfere with the attractiveness of the insects to traps, since this process is carried out by olfactory stimuli activated by chemical substances volatilized by plants or by attractants added to traps (Pavarini et al., 2018; Oliveira et al., 2018). Although Metamasius spp. has its population behavior probably influenced by environmental conditions, especially precipitation and $\mathrm{RH}$, it is observed that the $C$. sordidus infestation decreased along with the increase of insect collections. In this case, C. sordidus presented high infestation at the beginning of the experiment (August) and its population decreased as the number of collections increased, demonstrating that the bait was efficient in capturing the insect.

Considering that the average number of insects of $C$. sordidus captured in the baits was above the level of control ( 5 adults/bait/month) for most collections, the need for control accompanied by monitoring of the banana weevil borers is suggested, and $B$. bassiana can be used when opting for integrated pest management or even traps without attractants.

\section{Conclusions}

The baits were as efficient in collecting banana weevil bores as those containing the bioinsecticide and sugarcane molasses.

The successive captures of $C$. sordidus with the use of the roof tile-type bait promoted reduced the number of insects without the need for chemical control.

The behavior of Metamasius spp. may have been influenced by local weather conditions.

In two properties studied, in the month of greatest collection (October), two to three-fold more individuals of Metamasius spp. were collected in relation to $C$. sordidus.

Through collection using the tile-type bait, it was possible to verify high infestation of Metamasius spp. in the cultivar Pacovan.

\section{References}

AESA. Agência Executiva de Gestão das Águas do Estado da Paraíba (2020) Disponível em: $<$ http://www.aesa.pb.gov.br> (Acesso em 05 nov 2020).

Angelini MR, Queiroz AA (2016) Atratividade de Cosmopolites sordidus por genótipos de bananeira. Enciclopédia biosfera 13(24):120-127.

Bortoluzzi L, Alves LFA, Alves VS, Holz N (2013) Entomopathogenic nematodes and their interaction with chemical insecticide aiming at the control of banana weevil borer, Cosmopolites Sordidus Germar (Coleoptera: Curculionidae). Arquivos do Instituto Biológico 80(2):183-192. 
Dolinski C, Lacey LA (2007) Microbial control of arthropod pests of tropical tree fruits. Neotropical Entomology, 36(2):161-179.

Fancelli M (2012) Metamasius hemipterus L. como praga de bananeiras cv. Terra. Revista Brasileira de Fruticultura 34(3):944-946.

Fancelli M, Milanez JM, Mesquita ALM, Costa ACF, Costa JNM, Pavarini R, Pavarini G (2015) Artrópodes: pragas da bananeira e controle. Informe Agropecuário 36(288):7-18.

Gallo D, Nakano O, Silveira Neto S, Carvalho RP, Baptista GCD, Berti Filho E, ... Marchini LC (2002) Entomologia agrícola. FEALQ. 920 p.

IBGE - Instituto Brasileiro de Geografia e Estatística (2019) Sistema IBGE de recuperação automática. Banco de dados agregados. Produção agrícola municipal. 2019. Disponível em: <https://sidra.ibge.gov.br/pesquisa/pam/tabelas> (Acesso em 03 dez 2020).

Kochemborger J, Lopes LM, Silva Júnior EC, Sousa, $\mathrm{AH}$ (2016) Ocorrência de Metamasius hemipterus (Coleoptera: Curculionidae) em cultivos de bananeira no município de Senador Guiomard, Acre, Brasil. Revista de Biologia e Ciências da Terra 16(2):16-18.

López EA, Neves PMOJ, Fancelli M. (2012) Transmissão de fungo entomopatogênico no controle da broca do rizoma. Semina: Ciências Agrárias 33(6):2227-2231.

Moreira FJC, Araújo BA, Silva VF, Luna NS, Araújo OP, Braga RDS (2017) Controle de Cosmopolites sordidus (Coleoptera: Curculionidae) com os fungos entomopatogênicos Beauveria bassiana e Metarhizium anisopliae em banana. Revista Verde de Agroecologia e Desenvolvimento Sustentável 12(3):366-373.
Oliveira FT, Neves PMOJ, Bortolotto OC, Ventura MU (2018) Respostas olfativas do moleque-da-bananeira (Coleoptera: Curculionidae) para diferentes genótipos de bananeira. Revista Ceres 65(4):329-336.

Pauli G, Lopes RB, Alves SB, Junior ERD, Mascarin GM (2011) Falsa broca aumenta disseminação de Beauveria bassiana em populações de campo da broca-do-rizoma da bananeira. Ciência Rural 41(11):1867-1870.

Pavarini GMP, Demonari CG, Pavarini R, Souza IV (2018) Atração de adultos de Cosmopolites sordidus e Metamasius sp. (Coleoptera: Curculionidae) por armadilhas associadas a inseticida e proteína hidrolisada. Cultura Agronômica 27(1):148-159.

R CORE TEAM. R: A language and environment for statistical computing. $\mathrm{R}$ Foundation for Statistical Computing, Vienna, Austria, 2017. https://www.Rproject.org/.

Rojas JAR, Vargas CEM, Sebastián O (2019) Uso de trampas con atrayentes para el monitoreo de Cosmopolites sordidus y Metamasius spp. en plátano barraganete. Centro Agrícola 46(2):58-63.

Sousa DS, Pereira, WE (2016) Atividade agrícola do Brejo paraibano: declínio e tendências atuais. Revista Brasileira de Agropecuária Sustentável 6(3):11-20.

Treichel M, Kist BB, Santos CD, Carvalho CD, Beling RR (2016) Anuário Brasileiro da Fruticultura. Gazeta Santa Cruz. 88 p. 